Библиография произведений Н.В. Гоголя и литературы о нем на русском языке. 2018

V.A. Voropaev (Moscow, Russia)

\title{
The Bibliography of N.V. Gogol's Works and Literature about Him in Russian. 2018
}

\section{ПРОИЗ В Е ДЕНИЯ}

Вечера на хуторе близ Диканьки: [повести] / Ил. А. Лаптева. М.: Эксмодетство. Изд. И.П. Носова, 2018. 308, [2] с.: ил.: цв. ил. - (Золотое наследие). (Дружим с детства!). 3000 экз.

Вечера на хуторе близ Диканьки: [повести.] М.: Эксмодетство, 2018. 317, [2] с.: ил. (Классика). 7000 экз.

Вечера на хуторе близ Диканьки: [повести.] М.: АСТ, 2018. 349, [2] с. - (Школьное чтение). (Одобрено лучшими учителями).

Вечера на хуторе близ Диканьки: [повести.] М.: АСТ, 2018. 349, [2] с. - (Классика для школьников). 2000 экз.

Вечера на хуторе близ Диканьки: повести, изданные пасичником Рудым Паньком. М.: Время, 2018. 285, [2] с. - (Проверено временем). 5000 экз.

Вечера на хуторе близ Диканьки: [повести.] М.: Э, 2018. 538, [2] с. - (Всемирная литература). (Русская классика). 4000 экз.

Вечера на хуторе близ Диканьки: [повести.] М.: Э, 2018. 538, [2] с. - (Русская классика). 6000 экз.

Вечера на хуторе близ Диканьки: повести / Вступ. статья и примеч. И.А. Виноградова; худож. А.М. Лаптев. СПб.; М.: Речь. 2018. 416 с.: ил. - (Малая Классика Речи).

Загл. вступ. статьи: Видимое и сокровенное в «Вечерах на хуторе близ Диканьки» Н.В. Гоголя. C. $5-15$.

Примеч. С. 352-402.

Володина Т.В. Иллюстрации А.М. Лаптева. С. 403-414. 
Вечера на хуторе близ Диканьки: повести, изданные пасичником Рудым Паньком / Вступ. статья и коммент. И.А. Виноградова; рис. А. Лаптева. М.: Детская литература, 2018. 381, [2] с.: ил. - (Школьная библиотека). 5000 экз.

Загл. вступ. статьи: И по ту, и по эту сторону Диканьки. С. 5-46.

Коммент. С. 363-380.

Вечера на хуторе близ Диканьки: повести, изданные пасичником Рудым Паньком / Худож. А.М. Лаптев. СПб.; М.: Речь, 2018. 423, [2] с.: ил.: цв. ил. - (Малая Классика Речи). 5000 экз.

Вечера на хуторе близ Диканьки: повести. СПб.: Азбука; М.: Азбука-Аттикус, 2018. 544 с. - (Русская классика). 272 с. - (Больше чем книга). 4000 экз.

Вечера на хуторе близ Диканьки: повести / Худ. О. Коминарец. М.: Махаон, Азбука-Аттикус, 2018. 136 с.: ил.

Содерж.: Вечер накануне Ивана Купала; Майская ночь, или Утопленница; Ночь перед Рождеством.

Вечера на хуторе близ Диканьки: повести. М.: Изд-во «Э», 2018. 544 с. - (Русская классика).

Вечера на хуторе близ Диканьки: [сб.] М.: Изд-во АСТ, 2018. 320 с. - (Эксклюзив: Русская классика).

Вечера на хуторе близ Диканьки: повести / Худож. А.М. Лаптев. М.: Детская литератуpa, 2018. 192 с.: ил. - (Школьная библиотека).

Вечера на хуторе близ Диканьки: повести / Коммент. А.Д. Степанова; ил. А. Лаптева. СПб.: Азбука, <2018.>272 с.: ил.

Коммент. С. 252-270.

Вечера на хуторе близ Диканьки: повести, изданные пасичником Рудым Паньком / Ил. А. Лаптева. СПб.: Издание И.П. Носова: Азбука, 2018. 269, [2] с., [13] л. цв. ил.: ил. 4000 экз.

Вечера на хуторе близ Диканьки; Вий: [повести.] М.: АСТ, 2018. 349. [2] с: 3000 экз.

Вечера на хуторе близ Диканьки; [Миргород:] повести. М.: Изд-во Эксмо, 2018. 320 с. (Классика в школе).

Белинский В.Г. О русской повести и повестях г. Гоголя.

Вечера на хуторе близ Диканьки; Миргород: повести. М.: АСТ, 2018. 444, [2] с. - (Русская классика). 2000 экз.

Вий: повести М.: Мартин, 2018. 430, [2] с. - (Избранная классика. PocketBook). 2500 экз. Содерж.: Вий; Тарас Бульба; Ночь перед Рождеством; Повесть о том, как поссорился Иван Иванович с Иваном Никифоровичем и др.

Вий; Тарас Бульба: [повести.] М.: Эксмодетство, 2018. 268, [2] с.: ил. - (Классика с рисунками). 7000 экз.

Драматургия русских классиков. Пьесы: [сб.] / Сост., вступ. статьи Л. Калюжной. М.: Звонница-МГ, 2018. 495 с. 1000 экз.

Из содерж.: Ревизор.

Женитьба; Игроки: комедии / Вступ. статья, коммент. И.А. Виноградова; худож. Д.А. Дубинский. СПб.; М.: Речь, 2018. 192 с.: ил. - (Малая Классика Речи). 5000 экз. Загл. вступ. статьи: О комедиях Н.В. Гоголя «Женитьба» и «Игроки».

Монолог Гоголя в многоголосье «Женитьбы». С. 5-19. 
Смысл игры в комедии Гоголя «Игроки». С. 19-22.

Коммент. С. 178-190.

Записки сумасшедшего: повести. СПб.: Азбука, 2018. 284, [2] с. - (Азбука-классика).

Содерж.: Невский проспект; Нос; Портрет; Записки сумасшедшего.

Записки сумасшедшего: [повести] / Сост. Н. Волковой; ил. Анатолия Зверева. М.: Музей А3, 2018. 95 с.: ил. - (Гоголиада Анатолия Зверева).

Избранные комедии. М.: Мартин, 2018. 412, [2] с. - (Избранная классика). (Энциклопедия русской жизни). 2000 экз.

Из содерж.: Ревизор; Женитьба.

Комедии: [сб.] Москва: Мартин, 2018. 317, [2] с. - (Избранная классика). - (Рocket book). 2500 экз.

Из содерж.: Ревизор.

Малое собрание сочинений. СПб.: Азбука, Азбука-Аттикус, 2018. 832 с.

Содерж.: Вечера на хуторе близ Диканьки: повести; Миргород: повести; Из сборника «Арабески»: Нос, Портрет; Записки сумасшедшего; Ревизор: комедия в пяти действиях; Мертвые души: поэма.

Мертвые души: [поэма.] М.: Изд-во Эксмо, 2018. 320 с. - (Классика в школе).

Мертвые души: [поэма.] М.: Изд-во «Э», 2018. 352 с. - (100 главных книг). 3000 экз.

Мертвые души: [поэма. Т. 1.] М.: Изд-во АСТ, 2018. 352 с. - (Эксклюзив: Русская классика).

Мертвые души: [поэма. Т. 1-2] с иллюстрациями Марка Шагала / Худож. М. Шагал. М.: Изд-во АСТ, 2018. 416 с.: 96 ил. - (Коллекционная книга). 2000 экз.

[Впервые: Nikolas Gogol. Les Ames Mortes / Traduction de Henri Mongault. Eaux-fortes originales de Marc Chagall, 1-11. Paris, Teriade editeur, MCMXLVIII (Николай Гоголь. Мертвые души / Перевод Анри Монго. Оригинальные офорты Марка Шагала. Париж: Изд-во Териада, 1948). 368 экз.]

Мертвые души: поэма [Т. 1] / Примеч. А. Ашукина, А. Слонимского; худож. А.М. Лаптев. СПб.; М.: Речь, 2018. 416 с.: ил. - (Малая Классика Речи).

Примеч. С. 397-414.

Мертвые души: поэма [Т. 1-2] / Ил. А. Лаптева. СПб.: Азбука, 2018. 448 с.: ил.

Мертвые души: поэма, том первый / Коммент. И.А. Виноградова и В.А. Воропаева; худож. А.М. Лаптев. М.: Детская литература, 2018. 445, [2] с.: ил. - (Школьная библиотека). 5000 экз.

Приложения:

Аксаков К.С. Несколько слов о поэме Гоголя «Похождения Чичикова, или Мертвые души». C. 400-407.

Белинский В.Г. Несколько слов о поэме Гоголя «Похождения Чичикова, или Мертвые души». C. 408-412.

Boponaев B.A. Главы из книги «Н.В. Гоголь: жизнь и творчество».

История замысла и его осуществление. С. 413-415.

Смысл названия. С. 415-419.

Тема дороги. С. 419-421.

Притча о Кифе Мокиевиче и Мокии Кифовиче. С. 421-426.

Особенности поэтики. С. 426-431.

Коммент. С. 432-446.

Мертвые души: [поэма.] М.: АСТ, 2018. 413, [2] с.: ил. - (Русская классика). 
Мертвые души: поэма. М.: Изд-во АСТ, 2018. 416 с. - (Лучшая мировая классика). 10000 экз.

Мертвые души: поэма. М.: Изд-во Эксмо, 2018. 320 с. - (Русская классика). (Всемирная литература).

Мертвые души: поэма. СПб.: Лениздат, 2018. 319 с. - (Лениздат-классика). 2000 экз.

Мертвые души: поэма / Худож. А.М. Лаптев. СПб.; М.: Речь, 2018. 413, [2] с.: ил. - (Малая Классика Речи). 9000 экз.

Мертвые души: [поэма.] М.: АСТ, 2018. 347, [2] с. - (Русская классика). (Книги, изменившие мир. Писатели, объединившие поколения). 7000 экз.

Мертвые души: [поэма.] М.: Эксмо, 2018. 350 с. - (Pocket book). 5000 экз.

Мертвые души: поэма. М.: Время, 2018. 556, [1] с. - (Проверено временем). 5000 экз.

Миргород: повести / Худож. А. Симанчук. М.: Искателькнига. 2018. 93. [1] с.: ил. - (Библиотечка школьника).

Миргород: повести, служащие продолжением «Вечеров на хуторе близ Диканьки» / Худож. С.М. Дудин, Н.И. Ткаченко. СПб.; М.: Речь, 2018. 413, [2] с.: ил. - (Малая классика Речи). 4000 экз.

Ночь перед Рождеством: [повесть] М.: Издательский Дом Мещерякова, 2018. 64, [31] с.: ил.: цв. ил. - (Раскрываем классику). 7050 экз.

Ночь перед Рождеством: повесть / Худож. Евгений Антоненков. М.: Нигма, 2018. 90, [5] с.: цв. ил.

Ночь перед Рождеством: повести. Ростов-на-Дону: Проф-Пресс, 2018. 94, [1] с.: ил. (Школьная библиотека). 5000 экз.

Содерж.: Майская ночь, или Утопленница; Ночь перед Рождеством.

Пасхальные рассказы. М.: Олма: Абрис, 2018. 254, [1] с.: цв. ил. - (Русская классика в иллюстрациях). 1000 экз.

Из содерж.: Светлое Воскресенье.

Петербургские повести / Вступ. статья и коммент. В.А. Воропаева; худож. Ф. Москвитин. М.: Детская литература, 2018. 232 с.: ил. - (Школьная библиотека). 3000 экз.

Загл. вступ. статьи: Гоголевский Петербург. С. 5-14.

Коммент. С. 211-233.

Петербургские повести. М.: Эксмо, 2018. 221, [2] с. - (Всемирная литература). (Русская классика). 5000 экз.

Петербургские повести. М.: Э, 2018. 285 с. - (100 главных книг).

Петербургские повести. СПб.: Азбука: Азбука-Аттикус, 2018. 411, [3] с.- (Азбука-классика). 3000 экз.

Петербургские повести. М.: Эксмо, 2018. 285 с. - (Pocketbook). 3000 экз.

Содерж.: Невский проспект; Нос; Портрет; Шинель; Коляска; Записки сумасшедшего.

Полное собрание сочинений в одном томе / [Послеслов. Ю.В. Манна]. М.: Альфа-Книга, 2018. 1231 с.: ил. - (Полное собрание в одном томе). 3000 экз.

Загл. послесл.: Николай Васильевич Гоголь. С. 1211-1227.

Содерж.: Вечера на хуторе близ Диканьки. Миргород. Повести: Невский проспект; Нос; Портрет; Шинель; Коляска; Записки сумасшедшего; Рим (отрывок). Драматические произведения: Реви- 
зор: комедия в пяти действиях; Женитьба: совершенно невероятное событие в двух действиях. Мертвые души: поэма. Приложение: Предисловие ко второму изданию первого тома «Мертвых душ». Незаконченные произведения. Юношеские стихотворные произведения. Отрывки: Две главы из малороссийской повести «Страшный кабан»; Гетьман: роман. Мелкие отрывки: Ночи на вилле; Страшная рука; Фонарь умирал; Дождь был продолжительный; Рудокопов; Семен Семенович Батюшек; Девицы Чабловы; Хромой чорт. Драматические отрывки, отдельные сцены и черновые наброски: Игроки; Владимир третьей степени; Утро делового человека; Тяжба; Лакейская; Отрывок; Альфред; Отрывки из неизвестной драмы; Наброски драмы из украинской истории; Театральный разъезд после представления новой комедии. Юношеские стихотворные произведения: Ганц Кюхельгартен: идиллия в картинах; Новоселье; Акростих; Из поэмы «Россия под игом татар»; Италия. Публицистические и критические произведения: Статьи из сборника «Арабески»: Предисловие; Скульптура, живопись и музыка; О Средних веках; О преподавании всеобщей истории; Взгляд на составление Малороссии; Несколько слов о Пушкине; Об архитектуре нынешнего времени; Ал-Мамун; Жизнь; Шлецер, Миллер и Гердер; О малороссийских песнях; Мысли о географии; Последний день Помпеи; О движении народов в конце V века. Статьи и рецензии 1831-1842 гг.: Женщина; Борис Годунов: поэма Пушкина; О поэзии Козлова; О движении журнальной литературы в 1834 и 1835 году; Петербургские записки 1836 года. Рецензии из «Современника». Рецензии, не вошедшие в «Современник». Рецензия для «Москвитянина». Выбранные места из переписки с друзьями. Статьи 1846-1847 гг. (не напечатанные при жизни Гоголя): О «Современнике»; <Авторская исповедь>; О сословиях в государстве; Размышления о Божественной Литургии; Наброски и материалы по русской истории.

Размышления о Божественной Литургии. Минск: Изд-во Белорусского Экзархата, 2018. $128 \mathrm{c}$.

Ревизор: комедия в пяти действиях / Вступ. статья, коммент. И.А. Виноградова; худож. А.Д. Константиновский. СПб; М.: Речь, 2018. 192 с.: ил: цв. ил. - (Малая Классика Речи). 5000 экз.

Загл. вступ. статьи: Завязка «Ревизора». С. 5-24.

Коммент. С. 174-190.

Ревизор: [комедия: учащимся 8-х классов.] СПб.: Литера, 2018. 96, [1] с. - (Внеклассное чтение). 5000 экз.

Ревизор: комедия в пяти действиях. М.: Стрекоза, 2018. 125, [2] с.: ил. - (Школьная программа).

Ревизор: [сб.] М.: Изд-во АСТ, 2018. 224 с. - (Эксклюзив: Русская классика).

Содерж.: Ревизор; Женитьба.

Старосветские помещики (Из цикла «Миргород»): повести / Вступ. статья В. Гуминского, коммент. В. Воропаева; худож. А. Симанчук. М.: Детская литература, 2018. 173 с.: ил. - (Школьная библиотека). 3000 экз.

Загл. вступ. статьи: Гоголь и четыре урока «Миргорода». С. 5-14.

Коммент. С. $151-171$.

Содерж.: Старосветские помещики; Вий; Повесть о том, как поссорился Иван Иванович с Иваном Никифоровичем.

Старосветские помещики; Вий; Повесть о том, как поссорился Иван Иванович с Иваном Никифоровичем: [сб.: для среднего школьного возраста] / Худож. Сергей Любаев. М.: Нигма, 2018. 221, [2] с.: ил.: цв. ил. 1500 экз.

Тарас Бульба: повесть / Вступ. статья В. Воропаева; коммент. И. Виноградова; худож. Е.А. Кибрик. М.: Детская литература, 2018. 190 с.: ил. - (Школьная библиотека). 5000 экз. Загл. вступ. статьи: Гражданин земли Русской. С. 5-12.

Коммент. С. $167-188$.

Тарас Бульба: повесть / Вступ. статья и примеч. И.А. Виноградова; худож. Д.А. Шмаринов. СПб.; М.: Речь, 2018. 320 с.: ил. - (Малая Классика Речи). 5000 экз.

Загл. вступ. статьи: Узы небесного братства. С. 5-13. 
Примеч. С. 249-318.

Тарас Бульба: [повесть.] М.: АСТ, 2018. 317, [2] с. - (Классика для школьников) 2000 экз.

Тарас Бульба: [повесть] / Худож. Сергей Любаев. М.: Нигма, 2018. 204, [3] с.: ил.: цв. ил: 1500 экз.

Шинель: петербургские повести. М.: АСТ, 2018. 253, [2] с. - (Классика для школьников). (Рекомендовано лучшими учителями). 2000 экз.

Содерж.: Невский проспект; Нос; Портрет; Шинель; Записки сумасшедшего; Коляска.

Шинель: петербургские повести. М.: АСТ, 2018. 253, [2] с. - (Школьное чтение). 3000 экз.

Содерж.: Невский проспект; Нос; Портрет; Шинель; Записки сумасшедшего; Коляска.

\section{ЛИТЕРАТУРА}

Анненкова Е.И. Константин Аксаков. Веселье духа. СПб.: Росток, 2018. 328 с.

[Указ. имен.]

Анненская А.Н., Бриллиант С.М., Кривенко С.Н., Скабичевский А.М. Юмор - это серьезно: Гоголь, Крылов, Фонвизин, Салтыков-Щедрин и Грибоедов. [Предтеча ЖЗЛ Библиотека Ф. Павленкова.] М.: Родина, 2018. 480 с.

Анненская А.Н. Николай Гоголь. С. 7-91.

$<$ Арват H.H.> Профессор Нинель Арват. Ученый, педагог, человек: воспоминания и публикации / Сост.: Е. Петрик, Л. Гетман. Нежин: Издатель ЧП Лысенко Н.М., 2018. 272 с.

Из содерж: :

Изучение творческого наследия Н.В. Гоголя в нежинской высшей школе (лингвистический аспект). С. 23-29.

Формы и функции периода в художественных произведениях Н.В. Гоголя. С. 29-43.

«Сорочинская ярмарка» Н.В. Гоголя в переводах на украинский язык. С. 44-46.

Компаративное поле в «Вечерах на хуторе близ Диканьки» Н.В. Гоголя. С. 46-53.

Народно-разговорный компонент гоголевских сравнений («Вечера на хуторе близ Диканьки»). C. $54-58$.

К вопросу о гоголевском идиостиле (на материале повести «Страшная месть»). С. 58-70.

Об одной особенности в построении текста повести Н.В. Гоголя «Старосветские помещики». C. $70-78$.

Женщина в повести Н.В. Гоголя «Тарас Бульба». С. 78-86.

Описание как компонент структуры текста (повесть Н.В. Гоголя «Тарас Бульба»). С. 86-93.

Прямая речь как компонент структуры текста (повесть Н.В. Гоголя «Тарас Бульба»). С. 93-108.

Ритм в повести Н.В. Гоголя «Тарас Бульба». С. 108-127.

Композиционно-речевая структура повести Н.В. Гоголя «Вий». С. 140-152.

О троичности в повести Н. Гоголя «Вий». С. 153-166.

Ритмы повести Н. Гоголя «Вий». С. 166-178.

Троичность повести Н.В. Гоголя «Невский проспект». С. 179-186.

Речевое пространство в комедии Н.В. Гоголя «Ревизор». С. 186-196.

Бытовая картина мира в поэме Н. Гоголя «Мертвые души». С. 197-204.

Единство противоположностей как одна из черт поэтики Н.В. Гоголя («Мертвые души»). C. $204-212$.

О комплексном изучении картины мира в поэме Н.В. Гоголя «Мертвые души» (из опыта работы студенческого спецсеминара). С. 220-237.

Арват Ф.С., Арват Н.Н. О первых украинских переводах произведений Н.В. Гоголя. С. 237-245.

Цвет в семантическом поле художественно-изобразительных средств Н. Гоголя («Мертвые души»). С. 246-255.

Андреева Я.Ф., Арват Н.Н. Употребление колоративных прилагательных в повести Н.В. Гоголя «Тарас Бульба». С. 128-140.

Список публикаций Н.Н. Арват, посвященных творчеству Н.В. Гоголя. С. 256-263. 
Артамонова И.В. «Наполеоновские» коннотации в семантическом пространстве «Мертвых душ» Н.В. Гоголя // Материалы международного молодежного научного форума «Ломоносов-2018» / Отв. ред. И.А. Алешковский, А.В. Андриянов, Е.А. Антипов. Электронный ресурс] М.: МАКС Пресс, 2018.

Архангельский А.Н. Герои классики: продленка для взрослых. М.: Изд-во АСТ, 2018. 384 с. Гоголь. С. 231-350.

Аскоченская T.A. Вокруг света с Камерным театром. М.: Изд-во «Весь Мир», 2018. 312 с.: [8] л. ил.

[В частности, история создания оперы Д.Д. Шостаковича «Нос» (по одноименной повести Гоголя.] [Рец.: Баранкин E. Конец прекрасной эпохи. Вокруг света с Камерным театром // Музыкальная жизнь. М., 2018. № 7. С. 75-77.

О премьере оперы «Нос»

[Фрагмент из книги о подготовке к выпуску оперного спектакля «Нос» Д.Д. Шостаковича, репетициях Б.А. Покровского, дирижера Г.Н. Рождественского и премьере в Камерном музыкальном театре 12 сентября 1974 г.]

Бакии Л.С. «Шинель» Н.В. Гоголя. Две интерпретации одного сюжета // Музыковедение. М., 2018. № 9. С. 32-39.

[На примере двух работ композитора Александра Бакши по повести Гоголя «Шинель», созданных в соавторстве с режиссером Валерием Фокиным («Шинель» в театре «Современник») и режиссером анимационного кино Юрием Норштейном («Диалог с Юрием Норштейном о гоголевской “Шинели”»), рассматриваются разные типы музыкально-сценической драматургии.]

Барабаш Ю.Я. Улица Крокодилов / Невский проспект. И за их пределами. Бруно Шульц и Гоголь - встреча на пограничье // Studia Litterarum. M., 2018. Т. 3. № 2. С. 80-101. DOI: $10.22455 / 2500-4247-2018-3-2-80-101$

Баркина М.В., Овезова А.М., Смолина Ю.О. Наследие М.М. Бахтина в трудах ученых Мордовского университета в 1980-2010-х годах // E-Scio: научный электронный журнал. Саранск, 2018. № 4(19). С. 237-247.

[В частности, работы о Гоголе.]

Бекметов Р.Ф. Чичиков и «китайщина»: образ гоголевского героя в зеркале китайской классической традиции // Ученые записки Казанского ун-та. Серия: Гуманитарные науки. Казань, 2018. Т. 160. № 1. С. 42-65.

Белова Т.Н. Вклад В.В. Набокова в становление англо-американской русистики в 19401960-е гг. как переводчика и комментатора произведений русской литературы, академического исследователя и преподавателя американских университетов // Stephanos. 2018. № 3(29). C. 59-85.

[В.В. Набоков о Гоголе.]

<Белый А.> Литературное наследство. Т. 111: Андрей Белый. Жезл Аарона. Работы по теории слова 1916-1927 гг. / Сост., подгот. текста, вступ. статья, текстол. справки и коммент. Е.В. Глуховой, Д.О. Торшилова; отв. ред. О.А. Коростелев. М.: ИМЛИ РАН, 2018. 959 с.: [16] л. цв. ил.

[Указ. имен.]

Бердяев Н.А. Малое собрание сочинений. СПб.: Азбука, Азбука-Аттикус, 2018. 672 с. Русская идея. С. $185-215$.

Гл. 3. С. 216-227.

Гоголь и В.Г. Белинский. Религиозная драма Гоголя. Письмо Белинского к Гоголю. С. 222-225.

Бёмиг M. «Нос» Гоголя в контексте европейской «носологии» / Пер. с англ. Г. Ермошиной // Русская литература и журналистика в движении времени / Факультет журналистики. Московский гос. ун-т имени М.В. Ломоносова. М., 2018. № 1-1. С. 29-70. 
Бик-Булатов А.Ш. Образы и типы православного духовенства в русской журналистике XIX - начала XX века. СПб.: Дмитрий Буланин, 2018. 303 с.

Гл. 2: 1830-1850-е гг.: Н.В. Гоголь, В.Г. Белинский, П.Я. Чаадаев, А.С. Хомяков. С. 36-46.

[Указ. имен.]

Богатырева Л.В., Исупов К.Г. Русская классика в философской и литературной критике Серебряного века // Вестник русской христианской гуманитарной академии. СПб., 2018. T. 19. № 1. C. $280-289$.

[О Гоголе: С. 287.]

Бойкова И. Юность пушкинского театра в России... : В Пушкинском заповеднике прошел фестиваль молодежных театров «Михайловское-2018»// Вопросы театра / Гос. институт искусствознания. М., 2018. № 3-4. С. 73-88.

[Обзор спектаклей по мотивам произведений Гоголя.]

Братья Швальнеры. Гоголь. Вий. Не выходи из круга. [Б. м.:] Издательские решения, 2018. 268, [1] с. ил.

[Кн. создана в интеллектуальной издательской системе Ridero.]

Братья Швальнеры. Гоголь. Страшная месть [Б. м.:] Издательские решения, 2018. 271, [1] с.: ил.

[Кн. создана в интеллектуальной издательской системе Ridero.]

Брусиловский Н. Арбатские ворота // Историк: журнал об актуальном прошлом. М., 2018. № 9. С. 72-75.

[В частности, памятники Гоголю в Москве на Арбате.]

Бударагин М. [Рецензия] // Культура». М., 2018. № 29. С. 8.

[Рец. на фильм «Гоголь» (режиссер Е. Баранов, автор идеи А. Цекало).]

Варламова Н. Фарца в кривом зерцале. Вторая часть рецензии на к/ф-трилогию «Гоголь» // Русская народная линия. 10.11.2018 (ruskline.ru).

[Рец. на фильм «Гоголь» (режиссер Е. Баранов, автор идеи А. Цекало).]

[О первой части трилогии см.: Варламова Н. Горький смех не понять фарцовщикам. Рецензия на фильм «Гоголь. Начало» // Русская народная линия. 22.09.2017 (ruskline.ru).]

Василик Владимир, протодиакон. Солнце русской поэзии и грозы истории: К 180-летию со дня гибели А.С. Пушкина. М.: Изд-во Сретенского монастыря, 2018. 164 с.

Из содерж.:

Тема антихриста и Второго Пришествия в трагедии А.С. Пушкнна «Борис Годунов» и в комедии Н.В. Гоголя «Ревизор». С. 78-98.

Великий пост: произведения русских писателей / Сост. Т.В. Стрыгина. М.: Никея, 2018. 397 с. - («Пасхальный подарок»).

Из содерж.:

Bоропаев B. Жизнь и сочинения Николая Гоголя (Отрывок). Последние дни. С. 364-380.

Воропаев В. Лествица, возводящая на небо. С. 380-392.

Bepeсаев В.В. Гоголь в жизни: В 2 ч. М.: Изд-во Юрайт, 2018. - (Сер. Антология мысли). Ч. 1.319 c.; Ч. $2.311 \mathrm{c}$.

«Вечера на хуторе близ Диканьки» проданы на лондонских торгах за \$225 000 // Московский комсомолец. М., 2018. 1 декабря. № 264(27848). С. 2.

[На аукционе Christie's («Кристис») в Лондоне с молотка ушло первое издание сборника повестей Гоголя за рекордные 175000 фунтов, хотя первоначально оценивалось в 50-70 тысяч.]

Видугирите И., Максимова Е.С. Выбранные места // Практики и интерпретации: журнал филологических, образовательных и культурных исследований / Южный федеральный ун-т. Ростов-на-Дону, 2018. Т. 3. № 2. С. 7-18.

[Беседовала Е. Максимова.]

[В частности, о Гоголе.]

DOI $10.23683 / 2415-8852-2018-2-7-18$ 
Виноградов И.А. Винтажный код нашей культуры: Н.В. Гоголь // Литература в школе. М., 2018. № 10. С. 6-8.

Виноградов И.А. Гоголь и пути русской литературы: восходящее и нисходящее (Ф.М. Достоевский, И.С. Тургенев и др.) // И.С. Тургенев и русский мир: Материалы международной конференции к 200-летию писателя (Санкт-Петербург, Российская академия наук. Институт русской литературы, 29-31 октября 2018 г.) / Отв. ред. Н.П. Генералова, В.А. Лукина. М.: ИПО «У Никитских ворот», 2018. С. 26-29.

Виноградов И.А. Летопись жизни и творчества Н.В. Гоголя (1809-1852). Научное издание: В 7 т. / Российская академия наук. Институт мировой литературы им. А.М. Горького. М.: ИМЛИ РАН, 2018.

T. 4: $1842-1844.704 \mathrm{c}$.

T. 5: $1845-1847.928 \mathrm{c}$.

T. 6: $1848-1850.656 \mathrm{c}$.

T. 7: $1851-1852.640 \mathrm{c}$.

Виноградов И.А. Литературная проповедь Н.В. Гоголя: pro et contra // Проблемы исторической поэтики / Петрозаводский гос. ун-т; [редкол.: В.Н. Захаров (отв. ред.) и др.]. T. 16. № 2. Петрозаводск, 2018. С. 49-124. Интернет-ресурс: http://poetica.pro/files/ redaktor_pdf/1530266349.pdf

DOI 10.15393/j9.art.2018.5181

Виноградов И.А. Монолог Н.В. Гоголя в многоголосье «Женитьбы» // Проблемы исторической поэтики / Петрозаводский гос. ун-т; [редкол.: В.Н. Захаров (отв. ред.) и др.]. Петрозаводск, 2018. Т. 16. № 1. С. 66-102.

DOI 10.15393/j9.art.2018.4781

Виноградов И. Н.В. Гоголь и его современники о значении русского языка // Русская народная линия. 07.06. 2018 (ruskline.ru).

[К международному Дню русского языка.]

Виноградов И.А. Неизвестная полемика Н.В. Гоголя о наследии М.Ю. Лермонтова // Светская и духовная словесность в России XVIII-XIX веков / Российская академия наук. Институт мировой литературы им. А.М. Горького; отв. ред. М.И. Щербакова. М., 2018. С. 5-18.

Виноградов И.А. Новые датировки пятидесяти писем Н.В. Гоголя // Литературный факт: научный журнал. М.: ИМЛИ РАН, 2018. № 10. С. 393-427.

DOI 10.22455/2541-8297-2018-10-393-427

Виноградов И.А. «Огорченные люди» в творчестве Н.В. Гоголя // Проблемы исторической поэтики / Петрозаводский гос. ун-т; [редкол.: В.Н. Захаров (отв. ред.) и др.]. Петрозаводск, 2018. Т. 16. № 4. С. 29-114.

DOI 10.15393/j9.art.2018.5521

Виноградов И.А. Страсти по Гоголю. О духовном наследии писателя. М.: Изд-во Вече, 2018. 320 с. - (Вера и судьба).

Виноградская Н.Л. Ранние письма Н.В. Гоголя: проблемы текстологии и комментирования. По материалам круглого стола в ИМЛИ РАН // Литература в школе. М., 2018. № 12. С. 9-14. http://yspu.org/\%D0\%9B\%D0\%B8\%D1\%82\%D0\%B5\%D1\%80\%D0\%B0\%D1\%82\%D1\%83 $\% \mathrm{D} 1 \% 80 \% \mathrm{D} 0 \% \mathrm{~B} 0 \_\% \mathrm{D} 0 \% \mathrm{~B} 2 \_\% \mathrm{D} 1 \% 88 \% \mathrm{D} 0 \% \mathrm{BA} \% \mathrm{D} 0 \% \mathrm{BE} \% \mathrm{D} 0 \% \mathrm{BB} \% \mathrm{D} 0 \% \mathrm{~B} 5 \_2018-12$

Волгин И.Л. Родиться в России. Достоевский: начало начал. М.: Академический проект, 2018. 749 с.: цв. вкл. - (Игорь Волгин. Сочинения в семи томах).

[Указ. имен.]

Воропаев B.A. Библиография произведений Н.В. Гоголя и литературы о нем на русском языке. 1966-1980 // Stephanos. M., 2018. № 1(27). C. 211-263 (эл. изд.; www.stephanos.ru). DOI: 10.24249/2309-9917-2018-27-1-211-263. 
Воропаев B.A. Библиография произведений Н.В. Гоголя и литературы о нем на русском языке. 1955-1965 // Stephanos. M., 2018. № 3(29). С. 191-231 (эл. изд.; www.stephanos.ru). DOI: 10.24249/2309-9917-2018-29-3-191-231

Воропаев B.A. Библиография произведений Н.В. Гоголя и литературы о нем на русском языке. (1940-1954) // Stephanos. M., 2018. № 4 (30). C. 185-232 (эл. изд.; www.stephanos.ru). DOI: 10.24249/2309-9917-2018-30-4-185-232

Воропаев В.А. Библиография произведений Н.В. Гоголя и литературы о нем на русском языке. 1929-1939 // Stephanos. M., 2018. № 6 (32). C. 149-197 (эл. изд.; www.stephanos.ru). DOI: 10.24249/2309-9917-2018-32-6-149-197

Boponaeв B.A. Благословение Святой Горы: Русский Афон в судьбе Гоголя // Странникъ: историко-литературный журнал. Смоленск, 2018. № 2(9). С. 49-54.

Boponaев B.A. Благословение Святой Горы: Русский Афон в судьбе Н.В. Гоголя // Россия Византия - Афон: преемственность традиций в истории и культуре: сб. научных трудов / Отв. ред. О.В. Розина. М.: Изд-во Московского гос. областного ун-та, 2018. С. 55-62.

Boponaев B.A. Бытописатель Москвы. Об историке, этнографе, фольклористе Иване Михайловиче Снегиреве (1793-1868) // Московский журнал. История Государства Российского. М., 2018. № 9(333). Сентябрь. С. 24-32.

[В частности, И.М. Снегирев и Гоголь.]

Boponaев B. Гоголь в Сербии // Православное книжное обозрение. М., 2018. Март. № 3(80). C. 75.

[Рец. на кн.: Православни витез Николај Васиљевич Гогољ / Приредио и превео Ранко Гојковић. Стари Бановци; Београд: Бернар, 2017. 163 с. - (Библиотека Тихи глас).]

Bоропаев B.A. Гоголь и славянский мир [Окончание] // Даниловский благовестник. М.: Изд-во Данилова ставропигиального мужского монастыря, 2018. № 34. С. 39-46

[Начало см.: Даниловский благовестник. М., 2017. № 33. С. 19-26.]

Boponaев B.A. «Ей, гряди, Господи Иисусе». Кончина Гоголя как его завещание потомкам // Странникъ: историко-литературный журнал. Смоленск, 2018. № 3(10). С. 19-23.

Boponaев B.A. Записки доктора А.Т. Тарасенкова о последних днях жизни Н.В. Гоголя: научно-критический анализ [Электронный ресурс] // Язык и текст langpsy.ru 2018. T. 1. № 1. C. 23-54. http://psyjournals.ru/langpsy/2018/n1/Voropaev.shtml

Boponaев B.A. Катков и Гоголь: К постановке проблемы // Литература и религиозно-философская мысль конца XIX - первой трети XX века: К 165 -летию Вл. Соловьева / Отв. ред. и сост. Е.А. Тахо-Годи. М.: Водолей, 2018. - (Серия: Русская литература и философия: пути взаимодействия. Вып. 2). С. 190-197.

Boponaев B. Кончина Гоголя как завещание потомкам. К 165-летию смерти писателя // Православное книжное обозрение. М., 2018. Март. № 3(80). С. 26-34.

Boponaев B.A. Лествица преподобного Иоанна Синайского в жизни и творчестве Н.В. Гоголя // Русская речь. М., 2018. № 6. С. 101-108.

Boponaев B.A. М.М. Дунаев как историк русской литературы // Духовно-нравственное воспитание. М., 2018. № 3. С. 62-68.

Boponaев B.A. М.М. Дунаев как историк русской литературы // Русская народная линия 2018-09-06 (ruskline.ru).

http://ruskline.ru/analitika/2018/09/2018-09-06/mihail_mihajlovich_dunaev_kak_istorik 
Boponaев B. Михаил Катков и Николай Гоголь // История: научно-методический журнал для учителей истории и обществознания. М.: Издательский дом Первое сентября, 2018. № 7-8(624). Июль-август. С. 44-48.

https://yadi.sk/i/CPFDOMhA3aECJo

Bоропаев B.A. Православный Гоголь в Сербии // Stephanos. М., 2018. № 2(28). С. 332-333. DOI 10.24249/2309-9917-2018-28-2-332-333

[Рец. на кн.: Православни витез Николај Васиљевич Гогољ / Приредио и превео Ранко Гојковић. Стари Бановци; Београд: Бернар, 2017. 163 с. - (Библиотека Тихи глас).]

Bоропаев B.A. Святитель Игнатий (Брянчанинов) и Н.В. Гоголь: диалог о духовном и душевном // Язык, литература, культура: Актуальные проблемы изучения и преподавания: сб. научных и научно-методических статей / Московский гос. ун-т имени М.В. Ломоносова. Филологический факультет, кафедра русского языка для иностранных учащихся гуманитарных факультетов; редкол.: Л.П. Клобукова и др. Вып. 14. М.: МАКС Пресс, 2018. C. $72-80$.

Boponaев B. «Спаси меня, моя отрада». Молитва Н.В. Гоголя к Пресвятой Богородице // К единству! Журнал Международного общественного Фонда единства православных народов. М., 2018. Март-апрель. № 2(119). С. 38-41.

Boponaев B.A. Тайна великой поэмы // Поэзия филологии. Филология поэзии: сб. [материалов] конференции, посвященной А.А. Илюшину / Московский гос. ун-т имени М.В. Ломоносова; ред.-сост. В.Б. Катаев, Е. Пастернак; под общ. ред. Л. Безменовой, О. Кузнецовой, Е. Пастернак. Тверь: Издатель А.Н. Кондратьев, 2018. С. 108-112.

Boponaев B.A. Тарас Бульба: Удивительные факты, о которых не рассказывают в школе / Подгот. В. Каплан; рисунки Н. Кондратовой // [Электронный ресурс] https://foma. ru/taras-bulba-udivitelnyie-faktyi-o-kotoryih-ne-rasskazyivayut-v-shkole.html

Boponaев B.A. Тарас Бульба: Удивительные факты, о которых не рассказывают в школе / Подгот. В. Каплан; рисунки Н. Кондратовой // Фома: православный журнал для сомневающихся. М., 2018. № 12(188). Декабрь. С. 62-69.

Воропаев B.A. Требование Н.В. Гоголя на полях Библии // Русская речь. М., 2018. № 3. C. $77-81$.

DOI: $10.7868 / \mathrm{S} 0131611718030115$

Глушаков П. Шукшин, Гоголь и другие. Рассказ В. Шукшина «Забуксовал» // Вопросы литературы. М., 2018. № 1. Январь-февраль. С. 180-208.

Гоголезнавчі студії=Гоголеведческие студии / Редкол.: П.В. Михед (відп. ред.), О.Г. Ковальчук, С.Д. Абрамович, В.О. Воропаев, В.П. Казарин, О.С. Киченко, Г.В. Самойлденко; Ніжинський держ. ун-т ім. М. Гоголя; Гоголезнавчий центр; Інститут літератури ім. Т.Г. Шевченка НАН України. Вип. 7(24). Ніжин: ФОП Лук'яненко В.В. ТПК «Орхідея», 2018. 292 с. - (Гоголезнавчі студії). На рус. и укр. яз.

Из содерж.:

Абрамович С.Д. Цветок папоротника в повести Гоголя «Вечер накануне Ивана Купала» как архетип витального огня. С. 5-23.

Виноградов И.А. Винтажный код нашей культуры: Гоголь. С. 24-32.

Воропаев В.A. Гоголь и святоотеческое наследие. С. 33-49.

Евдокимов A.A. «Тарас Бульба» Н.В. Гоголя в свете трагедии У. Шекспира «Ромео и Джульетта». C. 50-63.

Казарин В.П., Новикова М.А. Н.В. Гоголь: «Страшная месть» - круг и чаша. С. 101-131.

Кривонос В.Ш. Путешествие в «другой» мир в прозе Гоголя. С. 144-156.

Рождественская И.Е. Н.В. Гоголь в восприятии польской литературной критики межвоенного двадцатилетия. С. 163-180. 
Шульи С.А. Пушкин, Гоголь, Л. Толстой (от «Барышни-крестьянки» к «Вию» и «Дьяволу»). C. $181-190$.

\section{Рецензії та відгуки:}

Bоропаев B.A. Гоголь в Сербии. Православни витез Николај Васиљевич Гогољ / Приредио и превео Ранко Гојковић. Стари Бановци; Београд: Бернар, 2017. 163 с. - (Библиотека Тихи глас). С. 208-209. Бібліографія:

Воропаев B.A. Библиография произведений Н.В. Гоголя и литературы о нем на русском языке (2016). C. 215-260.

Михед П.В., Костенко О.О. Бібліографія України про життя і творчість Миколи Гоголя (2016). С. 261-272. - На рус. и укр. яз.

Данилина Г.И., Хавралева О.В. Рецепция творчества Н.В. Гоголя в романе В.А. Шарова «Возвращение в Египет» // Вестник Тюменского гос. ун-та. Гуманитарные исследования. Humanitates. Тюмень, 2018. Т. 4. № 3. С. 140-152.

Данилина Г.И., Хавралева О.В. Рецепция классики в современной литературе: методический аспект (на материале романа В.А. Шарова «Возвращение в Египет») // Филологический класс / Уральский гос. педагогический ун-т. Екатеринбург, 2018. № 4(54). С. 86-91.

[Конспект занятия для студентов-филологов по дисциплине «Теория литературы» на материале романа современного прозаика В.А. Шарова «Возвращение в Египет» (2013), в котором автор с помощью библейских аллюзий (сюжет и метафорика книги «Исход») и разноуровневых отсылок к литературному наследию и биографии Гоголя показывает историю России как трагедию.]

Делекторская И.Б. «Жизнь с Гоголем» как вариант автобиографии (Об одном заглавии у Бориса Зайцева и жизнетворчестве Андрея Белого) // Литературный факт: научный журнал. М.: ИМЛИ РАН, 2018. № 8. С. 246-256.

Денисов В.Д. Петербургский текст Гоголя. СПб.: Нестор-История, 2018. 384 с.

Дерюгина Л.В. От смешного до великого... : Иван Тургенев о Гоголе // Светская и духовная словесность в России XVIII-XIX веков / Российская академия наук. Институт мировой литературы им. А.М. Горького; отв. ред. М.И. Щербакова. М., 2018. С. 85-96.

Дмитриева E.E. Миф о Беловодье, Опоньское царство староверов-бегунов и загадка второго тома Гоголя // Studia Litterarum. М., 2018. Т. 3. № 3. С. 116-143.

DOI: $10.22455 / 2500-4247-2018-3-3-116-143$

[Тема раскольников во 2 томе «Мертвых душ» Гоголя и легенда о Беловодье старообрядческой секты странников или бегунов.]

Дмитриева Е. Сад расходящихся тропок: С.Г. Бочаров о Гоголе // Вопросы литературы. М., 2018. № 3. Май-июнь. С. 279-285.

Долинин А. Кто же сказал «Все мы вышли из “Шинели” Гоголя»? // Русская литература. СПб., 2018. № 3. С. 163-170.

Дубровская С.А. «От Арзамаса» до Гоголя: смеховое слово в пространстве русской литературы 1810-х - начала 1840-х гг.: монография / Науч. ред. О.Е. Осовский. Саранск: Изд-во Мордовского ун-та, 2018. 252 с.

Дубровская С.A. Смеховое слово в карнавализованном пространстве эпистолярия Н.В. Гоголя // Филологические науки. Вопросы теории и практики. Тамбов, 2018. № 4-1(82). С. 13-16.

Дутко Н.П. Мир символов и смыслов в поэме Н.В. Гоголя «Мертвые души»: IX класс // Литература в школе. М., 2018. № 12. С. 24-26: ил. 
Жаворонкова М.Ю. Брачные мотивы в художественном мире Н.В. Гоголя // Филологические науки. Вопросы теории и практики. Тамбов: Изд-во Грамота, 2018. № 10-2(88). C. 250-255.

Ельниикая Л.М. Мифы русской литературы: Гоголь, Достоевский. Островский. Чехов. М.: ЛЕНАНД, 2018. 208 с.

Н.В. Гоголь. С. $10-57$.

Завгородний А.М. Рецепция поэмы Н.В. Гоголя «Мертвые души» во Франции: между двумя мировыми войнами XX в. // Вестник Томского гос. ун-та. Томск, 2018. № 426. С. 14-26.

Завгородний А.М. Французская рецепция поэмы Н.В. Гоголя «Мертвые души»: Вторая мировая война - начало XXI в. // Вестник Томского гос. ун-та. Томск, 2018. № 428. С. 17-28.

Завгородняя Д. А отдыхать кто будет? Пушкин? На каких курортах вдохновлялись и поправляли здоровье классики русской литературы // Комсомольская правда. М., 2018. 2-9 авг. С. 33-34.

Гоголь, Рим и макароны. С. 33.

Зайцев Б.К. Отблески Вечного: неизвестные рассказы, эссе, воспоминания, интервью / Сост., вступ. статья, подгот. текста и коммент. А.Л. Любомудрова. СПб.: Изд-во «Росток», 2018. 736 с.: ил.

[Указ. имен.]

Заславский О.Б. Слово и сюжет в «Пропавшей грамоте» Н.В. Гоголя // Сюжетология и сюжетография / Институт филологии Сибирского отделения Российской академии наук. Новосибирск, 2018. № 1. С. 105-120.

DOI: $10.25205 / 2410-7883-2018-1-105-120$

Зырянов О.В. Введение в этнопоэтику русской классической литературы: учебное пособие. М.: Флинта; Екатеринбург: Изд-во Уральского ун-та, 2018. 216 с.

Гл. 8: Три типа гуманизма и проблемы рецепции гоголевской «Шинели». С. 156-171.

Икона в русской словесности и культуре: Материалы XIV Международной научной конференции (Москва, 25-27 января 2018 г.) / Дом Русского зарубежья им. Александра Солженицына. Музей русской иконы; ред.-сост. проф. В.В. Лепахин. М., 2018. 389 с. [Электронный ресурс]

\section{Из содерж.:}

Гуминский B.M. Гоголевское пространство и древнерусская традиция. С. 267-278.

Закуренко А.Ю. Гоголь и симулякры: святитель Игнатий Брянчанинов и оптинские старцы о Выбранных местах из переписки с друзьям. С. 279-289.

История России с древнейших времен до наших дней / А.Н. Боханов и др.; под ред. А.Н. Сахарова. М.: Изд-во АСТ, 2018. 1744 с.

[О Гоголе: С. 1055-1058.]

Кайгородиева Ю.Б., Панова О.Б. Этика слова и языка в позднем творчестве Н.В. Гоголя (на основе «Выбранных мест из переписки с друзьями») // Язык и культура / Национальный исследовательский Томский гос. ун-т. Томск, 2018. № 41. С. 102-124.

Карташов В.С. Ботанические тексты Н.В. Гоголя. Ч. 2. М.: Изд-во Спутник+, 2018. 26 с. 20 экз.

Катаев В.Б. К пониманию Чехова: статьи / Институт мировой литературы им. А.М. Горького Российской Академии наук. М.: ИМЛИ РАН, 2018. 247 с.

[Указ. имен.]

Кафанова О.Б. Дебюты И.С. Тургенева-переводчика // Русский язык и культура в зеркале перевода / Высшая школа перевода (факультет). Московский гос. ун-т имени М.В. Ломоносова. М., 2018. № 1. С. 78-90.

[И.С. Тургенев - переводчик Гоголя; С. 83-89.] 
Каширина В. Письма Затворника Георгия // Православное книжное обозрение. М., 2018. Март. № 3(80). С. 42-47.

[Гоголь и оптинский монах Порфирий (Григоров), издатель «Писем в Бозе почивающего затворника Задонского Богородицкого монастыря Георгия»: С. 44-46.]

Классики и современность: Гоголь, Тургенев, Горький / Сост. А. Вранеш, Л. Маркович, А. Шешкен. Белград: Филологический факультет Белградского ун-та; М.: Московский гос. ун-т имени М.В. Ломоносова; Тюмень: Тюменский гос. ун-т; Воронеж: Воронежский гос. ун-т, 2018. 315 с. - (Библиотека Язык и литература. Сер. Труды о языке и литературе; кн. 19). Из содерж::

Bоропаев B.A. Гоголь и славянский мир. С. 7-38.

Сорокина В.В. Гоголь в XXI веке. Новые исследования творчества писателя на Западе. С. 39-56. Злочевская А.В. «Ревизор» Н.В. Гоголя - парадоксы экспериментальной поэтики. С. 57-70.

Моисеева В.Г. Барочный Гоголь Терца-Синявского. С. 71-86.

Евдокимов А.А. К проблеме шекспировского текста в поэме Н.В. Гоголя «Мертвые души». C. $87-100$.

Белова Т.Н. В. Набоков - критик Н.В. Гоголя (к проблеме научного подхода). С. 101-120.

Мещеряков С.Н. Современность классики: в художественном мире Гоголя и Павича. С. 121-142.

Шешкен А. «Гоголевская шинель» для македонского писателя (проза Димитара Солева). С. 143-160.

Сартаков Е.В. Первые сведения о Гоголе в сербской печати (1838-1849 годы). С. 161-184.

[Рец.: Осипова Е.A. К вопросу о русско-сербских литературных пересечениях // Два века русской классики: научный журнал. М., 2019. № 1. С. 148-157. DOI 10.22455/2686-7494-2019-1-1-148-157]

Козодаева Г.С. Рождественский квест «Приключения на хуторе близ Диканьки» // Методист. М., 2018. № 8. С. 33-36.

[Методическая разработка Рождественского квеста с детьми разного возраста. На материале произведений Гоголя.]

Клокова Л. Под серебряным небом. Николай Васильевич Гоголь называл Рим «родиной своей души» // Русский мир.ru. М., 2018. 16 сент. № 11. С. 86-96.

Колмакова O.А. Трансформация мифа о Гоголе в повести А. Королева «Голова Гоголя» // Вестник Бурятского гос. ун-та. Улан-Удэ, 2018. № 2-1. С. 36-41.

Комарович В.Л. «Весь устремление»: статьи и исследования о Ф.М. Достоевском / Сост., отв. ред. вступ. статья О.А. Богдановой; подгот. текста и коммент. О.А. Богдановой, Т.А. Кошемчук, А.Б. Криницына, Г.И. Романовой, Б.Н. Тихомирова; пер. с нем. А.Б. Криницына. М.: ИМЛИ PAH, 2018. $927 \mathrm{c}$.

[Указ. имен.]

Кошелев B.A. «...Вся Коломна и петербургская природа живая...»: «Домик в Коломне» А.С. Пушкина и повесть Н.В. Гоголя «Портрет» // Проблемы исторической поэтики / Петрозаводский гос. ун-т; [редкол.: В.Н. Захаров (отв. ред.) и др.]. Петрозаводск, 2018. T. 16. № 1. С. 44-65.

Кривонос В.Ш. «Мертвые души» Гоголя: Пространство смысла: монография. 3-е изд., испр. и доп. М.: Флинта: Наука, 2018. 320 с.

Кузнецов И.В. Мотив замерзания / заморозки в новейшей русской прозе // Сюжетология и сюжетография / Институт филологии Сибирского отделения Российской академии наук. Новосибирск, 2018. № 1. С. 160-167.

DOI 10.25205/2410-7883-2018-1-160-167

[Гоголевская трактовка мотива холода (повесть «Шинель») в русской литературе XXIв.]

Курганов Е.Я. Анекдот и литературно-придворный быт. М.: Издательский центр «Азбуковник», 2018. 384 с.

Приложение II: Анекдоты русских писателей (К проекту антологии). С. 325-329.

Н.В. Гоголь. С. 328-329. 
[Впервые: Anecdotica. Из записной книжки П.И. Миллера // Новое литературное обозрение. М., 1993. № 3. С. 203-208. Н.В. Гоголь С. 294-205.]

Куркин Б. Русское колесо. Размышления над первой сценой «Мертвых душ» // Литература в школе. М., 2018. № 11. С. 13-15.

Курлов Д.В. «Искусство фантастического»: художественные представления Г. Газданова в 1920-е гг. // Филология и культура / Казанский (Приволжский) федеральный ун-т. Казань, 2018. № 3(53). С. 169-174.

[Литературно-критическое эссе Г. Газданова «Заметки об Эдгаре По, Гоголе и Мопассане».]

Кучина E.C. «Не собирайте сокровищ на земле»: методические рекомендации к изучению повести Н.В. Гоголя «Шинель». IX-X классы // Литература в школе. М., 2018. № 10 . C. 35-38.

Манянина (Маливанова) Е.И. Лечение Н.В. Гоголя в Остенде и Грефенберге // Научный диалог. Екатеринбург, 2018. № 1. С. 83-95.

http://nauka-dialog.ru/arxiv/2018/nauchnyij-dialog-2018-1/10-01-00-literaturovedenie-zhurnalistika/ lechenie-n-v-gogolya-v-ostende-i-grefenberge.html

DOI: $10.24224 / 2227-1295-2018-1-83-95$

Маркович B.M. О Тургеневе: работы разных лет / Под ред. Е.Н. Григорьевой, Е.И. Ляпушкиной. СПб.: «Росток», 2018. 542 с.

Из содерж.:

И.С. Тургенев и русский реалистический роман XIX века

Гл. 1: Некоторые особенности реализма в романах Пушкина, Лермонтова, Гоголя («Евгений Онегин», «Герой нашего времени», «Мертвые души»). С. 146-222.

[Указ. имен.]

Медведев П.Н. Собрание сочинений: В 2 т. / Изд. подгот. Ю.П. Медведев и Д.А. Медведева; отв. ред. Б.Ф. Егоров. СПб.: Изд-во «Росток», 2018.

Т. I: История литературы. 848 с.: ил. 300 экз.

Из содерж.:

О Гоголе. 1852-21-II-1917. С 189-194.

[Впервые: Бессарабская жизнь. Кишинев, 1917. 21 февраля. № 50. С. 2.]

Неистовый Аполлон <Об Ап.А. Григорьеве>. С. 152-157.

[C. 153: «...тот “новый настоящий Гоголь”, о котором столько интересных мыслей высказали в последние годы Мережковский и Гершензон, Брюсов и А. Белый, есть старый Гоголь Ап. Григорьева...».]

[Впервые: Бессарабская жизнь. Кишинев, 1916. 17 апр. № 88. С. 2.]

Т. 2: Поэтика и психология творчества. 928 с.: ил. 300 экз.

[Указ. имен.]

Меладиина Ю.В. Идейно-художественные параллели между героями комедии Н.В. Гоголя «Ревизор» и исполнителями их ролей в романе В. Шарова «Возвращение в Египет» // Вестник Удмуртского ун-та. Серия История и филология. Ижевск, 2018. Т. 28. № 3. С. 373-381.

Меладшина Ю.В. Образ Хлестакова в романе В. Шарова «Возвращение в Египет» // Актуальные вопросы филологической науки XXI века: сб. статей VII Международной научной конференции молодых ученых (9 февраля 2018 г). Екатеринбург, 2018. Ч. 2: Современные проблемы изучения истории и теории литературы. С.-87-94.

Меладиина Ю.В. Преображение Павла Ивановича Чичикова в романе Владимира Шарова «Возвращение в Египет» // Вестник Удмуртского ун-та. Ижевск, 2018 Т. 28. № 5. С. 727-736.

Мелетинский Е. Поэтика мифа. СПб.: Азбука: Азбука-Аттикус, 2018. 480 с. - (Новый культурный код).

[Указ. имен.] 
$<$ Меншиков М.О.> Михаил Осипович Меншиков: [сб.] / Подгот. А.В. Воронцова. М.: Русскій Міръ, 2018. 800 с.: ил. - (Русскій Міръ в лицах).

Из содерж.:

Драма Гоголя. С. 204-209.

Он не ваш (Н.В. Гоголь). С. 265-270.

Мережковский Д.С. Собрание сочинений: В 20 т. Т. 8: Вечные спутники / Сост., подгот. текста, примеч., послесл. Е.А. Андрущенко. М.: Дмитрий Сечин, 2018. 447 с.

[Указ. мен.]

$<$ Мережковский Д.С.> Д.С. Мережковский: писатель - критик - мыслитель: сб. статей / Ред.-сост.: О.А. Коростелев, А.А. Холиков. М.: Изд-во «Дмитрий Сечин», Литфакт, 2018. 687 с.

Из содерж.:

Виноградов И.А. «Отрекись от Пушкина!» Требовал ли этого от Гоголя протоиерей Матфей Константиновский? (Источниковедческий анализ). С. 38-49.

Коптелова Н.Г. Миф о Пушкине в критическом исследовании Д.С. Мережковского «Гоголь и черт». С. 149-156.

[Указ. имен.]

Мильдон В.И. Невольное поведение персонажей Гоголя // Вестник ВГИК / Всероссийский гос. институт кинематографии им. С.А. Герасимова. М., 2018. № 4(38). С. 54-61.

Муминов С.О. Изучение литературной комики Д.И. Фонвизина, А.С. Грибоедова и Н.В. Гоголя в школе: учебное пособие. 3-е изд., стер. М.: Флинта: Наука, 2018. 112 с. Анализ комического начала в поэме Н.В. Гоголя «Мертвые души. С. 82-102.

Недзвеикий А. Ревизор идет к вам, или Дом, который построил Шурик // Театральный курьер. М., 2018. № 3(193). С. 3 (продолжение следует).

[О премьере спектакля «Ревизор. Версия» в театре «Et Cetera» (художественный руководитель А.А. Калягн, режиссер Роберт Стуруа, роль Хлестакова сыграл А.А. Калягин).]

Нижников С.А. Н.В. Гоголь и В.Г. Белинский: поверх стереотипов // Электронное научное издание Альманах Пространство и Время. М., 2018. Т. 16. № 1-2. С. 10.

DOI 10.24411/2227-9490-2018-11051

Новикова-Строганова А.А. Слово должно быть свято // Русский вестник. М., 2018. 31 мая. [Христианские идеи Гоголя.]

Новикова-Строганова А.А. Слово должно быть свято // Русская народная линия. 08.06.2018 (ruskline.ru).

Носов С. Тайная жизнь петербургских памятников. СПб.: Лимбус Пресс, Изд-во К. Тублина, 2018. 240 с.: ил.

Из содерж:

Гоголь незримый. С. 60-70.

[Неосуществленный замысел памятника Гоголю на Манежной площади в Санкт-Петербурге.]

Образование в XXI веке: традиции и новации: Материалы международной научно-практической конференции. Вып. 1: К 80-летию проф. Е.Н. Колокольцева / Министерство образования Московской области; Московский гос. областной ун-т; отв. ред. Т.М. Воителева, А.В. Шмелева. М., 2018. 348 с.

Из содерж.:

Boponaев B.A. Жизнь и традиция: кончина Гоголя как его завещание потомкам. С. 260-266.

Гладилин М.С. Чичиков и анти-Христос. С. 267-271.

Макиенко К.И. Н.В. Гоголь в исследованиях С.И. Пономарева. С. 309-314.

Овчинников Д.П. Изучение ритма прозы Н.В. Гоголя на уроках литературы // Научный поиск. Шуя: Изд-во Технологический центр, 2018. № 2(28). С. 41-44. 
Овчинников Д.П. Окно и «узники пещеры» в «Женитьбе» Н.В. Гоголя // Университетский научный журнал. СПб.: Санкт-Петербургский университетский консорциум, 2018. № 38. C. 176-187.

Орехов B.B. «Наднациональная» задача национального автора в осмыслении В.Г. Белинского // Ученые записки Крымского федерального университета имени В.И. Вернадского. Филологические науки. Симферополь, 2018. Т. 4(70). № 2. С. 40-52.

[В частности, В.Г. Белинский о Гоголе.]

Осокин М.Ю. «Приезжий во всем как-то умел найтись...» (Хрисолог Ж.-Б. Руссо и Чичиков Н.В. Гоголя) // Русская речь. М., 2018. № 2. С. 60-64.

[Эпиграмма Ж.-Б. Руссо «Хрисолог всегда высказывает свое суждение...» как возможный источник или образец фрагмента «Мертвых душ» Гоголя о способности Чичикова поддержать любой разговор в обществе провинциального города N.]

Падерина Е.Г. К истории сохранения и первых публикаций черновых рукописей Гоголя: вопросы, проблемы, новые материалы // Вестник славянских культур. М., 2018. Т. 50. C. $165-177$.

[Судьба черновых рукописей Гоголя. Публ. «Реестр черновых бумаг Н.В. Гоголя», отправленных наследниками в Москву для подготовки 10-го издания сочинений писателя (ОР РГБ).]

Панов С.И. Неизданная статья С.Н. Дурылина о стихотворении П.А. Вяземского «Орфографическое замечание» // Литературный факт: научный журнал. М.: ИМЛИ РАН. 2018. № 10. С. 321-354.

[В частности, С.Н. Дурылин о Гоголе.]

DOI 10.22455/2541-8297-2018-10-321-354

Панова Л.Г. Мнимое сиротство: Хлебников и Хармс в контексте русского и европейского модернизма. 2-е изд., испр. и доп. М.: Издательский дом Высшей школы экономики, 2018. 605, [2] с. - (Исследования культуры).

[Указ. имен.]

[1-е изд. М., 2017.]

Певак E.A. Гоголь в зеркале русского модернизма // Stephanos. 2018. № 5(31). C. 51-62. DOI 10.24249/2309-9917-2018-31-5-51-62

Писарева Е. Ирина Муравьева - лучшая сваха. Юрий Соломин поставил Гоголя // Московский комсомолец. М., 2018. 25 окт. № 234(27818). С. 5.

[В Москве в Малом театре спустя 175 лет после премьеры (1843) режиссер Юрий Соломин поставил «Женитьбу» Гоголя. Роль свахи Феклы Ивановы исполнила И. Муравьева.]

Плаксин С.Г. Н.В. Гоголь в портретах, скульптуре, поэзии и мемуарах современников. М.: Сам Полиграфист, 2018. 520 с.: ил.

[Указ. имен.]

Подорога B. Nature Morte. Строй произведения и литература Н. Гоголя / Институт философии РАН. М.: РИПОЛ классик, 2018. 384 с.: ил. - (МИМЕСИС).

Поэзия филологии. Филология поэзии: сб. [материалов] конференции, посвященной А.А. Илюшину (Москва, 17-18 февраля 2017 г.) / Московский гос. ун-т имени М.В. Ломоносова; ред.-сост. В.Б. Катаев, Е. Пастернак; под общ. ред. Л. Безменовой, О. Кузнецовой, Е. Пастернак. Тверь: Издатель А.Н. Кондратьев, 2018. 271 с.

Из содерж.:

Евдокимов А.А. О генезисе ноктюрнальности в «Вечерах на хуторе близ Диканьки» Н.В. Гоголя. C. $45-50$.

Воропаев В.A. Тайна великой поэмы. С. 108-112.

Просветитель и романтик: памяти профессора Московского университета А.А. Смирнова (1941-2014) / Сост. общ. ред., вступ. статья, подгот. научных статей А.А. Смирнова и библиографического перечня его работ А.В. Лебедева; подгот. архивных материалов А.В. Лебедева, А.В. Алексеева. М.; СПб.: Нестор-История, 2018. 616 с.: ил. 


\section{Из содерж.:}

Михед П.В. Гоголь в канонах украинской и русской культур (замечания к проблеме). С. 194-202. Лебедев A.B. Гоголевские интертексты как один из способов воплощения феномена «кухонного витийства» в поэзии Л.В. Лосева. С. 378-390.

Расев А.И., <протоиерей>. Очерк жизни в Бозе почившего Ржевского протоиерея о. Матфея Александровича Константиновского: Сводная редакция (1860-1890-1915) / [Вступ. статьи В. Воропаева; протоиерея А. Шабанова; примеч. протоиерея А.И. Расева (в тексте)]. [2-е изд.] Тверь, <2018>. 496 с.

[Издано по благословению епископа Ржевского и Торопецкого Адриана. На титуле 2017.]

Из содерж.:

Воропаев B. Оставаться на капитанском мостике до конца. Несколько слов о протоиерее Алексии Расеве и его книге. С. 12.

Шабанов А., протоиерей. Протоиерей Алексей Расев. In Memoriam. С. 13.

Щеглов И. Гоголь и о. Матвей Константиновский. С. 370-383.

[Впервые: Новое Время. 1901. 13 дек. № 9260. С. 2-3. Загл.: Гоголь и о. Матвей Константиновский (История одного губительного недоразумения).]

Поселянин. Е. Гоголь и прот. Матфей Ржевский. С. 384-388.

[Статья-реплика на статью И. Щеглова.]

[Впервые: Московские Ведомости. 1902. 27 февр. / 12 марта. № 57. Передовица.]

А.Н. <Александр Надеждин> Ржевский протоиерей Матфей Константиновский и отношение к нему Н.В. Гоголя. С. 389-395.

[Впервые: Православно-Русское Слово. 1902. Февр. № 4. С. 275-293.]

Воспоминания прот. Феодора Образцова. С. 396-411.

Из воспоминаний Е.Н. Бастамовой. С. 429-431.

Суждение Д.С. Мережковского. С. 432-447.

Неизданное письмо о. Матфея Н.В. Гоголю. С. 458-460.

Известные письма странника-Гоголя о. Матфею. С. 461-470.

Введенский А.П., священник. Духовник Н.В. Гоголя. С. 478-488.

Ревяков И.С. А.С. Пушкин и Н.В. Гоголь как пределы бытия в художественной действительности произведений Даниила Хармса // Культура в фокусе научных парадигм / Донецкий национальный ун-т. Донецк, 2018. № 8. С. 127-133.

[На материале двух произведений Д. Хармса, а именно: «Пушкин и Гоголь» и «О Пушкине», в которых А.С. Пушкин и Гоголь выступают в качестве их героев.]

Роготнев И.Ю. Литературная тайна в эстетической коммуникации // Социо- и психолингвистические исследования / Пермский гос. национальный исследовательский ун-т. Пермь, 2018. № 6. С. 135-140.

«Завещание» Н.В. Гоголя. С. 137-138.

Русская классика: pro et contra: Железный век: антология / Русская христианская гуманитарная академия; сост., вступ. статьи и коммент. И.А. Есаулова, Т.Г. Петровой; отв. ред. Д.К. Богатырев. СПб.: РХГА, 2018. 1086 с. - (Русский Путь: pro et contra). (Русская классическая литература в мировом контексте). 300 экз.

Есаулов И.А. Рецепция отечественной классики в период русской катастрофы. С. 9-42.

Из содерж.:

I. Русская классика: советский вектор истолкования, предтечи и попутчики

Эйхенбаум Б.М. Как сделана «Шинель» Гоголя. С. 68-85.

Тынянов Ю.Н. Достоевский и Гоголь (к теории пародии). С. 86-118.

Бердяев Н.А. Духи русской революции. С. 237-273.

Переверзев В.В. Гоголь. С. 373-383.

II. Русская классика и русское зарубежье

Петрова Т.Г. Русская классика в литературной критике эмиграции. С. 479-500.

Н.В. Гоголь

Бем А.Л. «Шинель» и «Бедные люди». С. 576-587.

Франк С.Л. Религиозное сознание Гоголя. С. 588-598.

Чижевский Д.И. Неизвестный Гоголь. С. 599-630. 
Зеньковский B.B., протопресвитер. Русские мыслители и Европа <Фрагмент>. С. 631-643.

Флоровский Г.В., протоиерей. Три учителя. Искание религии в русской литературе девятнадцатого века. С. 1012-1020.

[В частности, о Гоголе.]

Коммент. С. 1021-1080.

[То же: М., 2017.]

[Реф.: Гришина Т.Г. // Социальные и гуманитарные науки в России. Сер. 7. Литературоведение. Реферативный журнал ИНИОН РАН. М., 2019. № 1. С. 186-189.]

Русская классика: pro et contra. Между Востоком и Западом: антология / Русская христианская гуманитарная академия; сост. Л.В. Богатыревой и др.; вступ. статья Л.В. Богатыревой и К.Г. Исупова. СПб.: РХГА, 2018. 1072 с. - (Русский Путь).

Загл. вступ. статьи: Русская литература глазами Запада и Востока. С. 8-22.

Коммент. С. 931-1063.

Из содерж.:

Масарик Томаш. Россия и Европа: эссе о духовных течениях в России <Фрагмент.> С. 94-110. [О Гоголе: С. 103 и др.]

Бэринг Морис. Краткий обзор русской литературы <Фрагменты.> / Пер. с англ. Ю.В. Филлиповой. С. 111-117.

[На русском языке публ. впервые.]

[О Гоголе: С. 113-116.]

[Впервые: Baring M. An Out Line of Russian Literature. London, 1915.]

Каснер Рудольф. Великие русские. С. 239-241.

[О Гоголе. С. 240.]

Каснер Рудольф. О русских писателях. С. 242-245.

[О Гоголе. С. 242.]

Моэм Сомерсет. Записные книжки <Фрагменты.>

[О «Ревизоре» Гоголя: С. 126.]

Манн Томас. Русская антология. С. 212-222.

[О Гоголе: С. 214-216, 218-219.]

Биллингтон Джеймс. Икона и топор: Опыт истолкования истории русской культуры. С. 267-293.

[О Гоголе: С. 275-281 и др.]

Шпидлик Томаш. Русская идея: иное видение человека <Фрагменты.> С. 294-302.

Воплощение зла и добра в людях: Портрет Гоголя. С. 301.

Никё Мишель. Западные источники русской души. С. 312-316.

[О Гоголе: С. 314-316.]

Сиоран Эмиль. Искушение существованием. Х. Ярость и безропотность. Гоголь. С. 587-590.

[Впервые: Sioran E. La tentation d'exister. Editions gallimard. Paris, 1956.]

Помпео Лоренио. Итальянские исследования о русских писателях-классиках в 90-е годы XX в.

C. 811-821.

[Публ. впервые.]

[О Гоголе: С. 813, 814-815, 820-821.]

C.Г. <Реферат > // Культурология / Институт научной информации по общественным наукам Российской академии наук. М., 2018. № 3. С. 59-65.

[Реф. статьи: Новикова-Строганова А. Н.С. Лесков и Н.В. Гоголь // Сетевой журнал «Камертон». Режим доступа: http://webkamerton.ru/2017/12/ns-leskov-i-nv-gogol]

Савинков C.B. Немецкий дискурс в русском тексте Н.В. Гоголя // Русская и немецкая литература в диалоге / Под ред. М. Фрайзе и А.А. Фаустова. Воронеж, 2018. С. 213-225.

Салтымакова О.А. Мотив торговли в повести Н.В. Гоголя «Сорочинская ярмарка» // Актуальные вопросы фундаментальных наук в техническом вузе: сб. научных статей / Кузбасский гос. технический ун-т им. Т.Ф. Горбачева. Кемерово, 2018. С. 242-250.

Сартаков E.B. Гоголь и Тургенев (к истории ссылки писателя в Спасское) // Спасский вестник / Гос. мемориальный и природный музей-заповедник И.С. Тургенева «Спасское-Лутовиново». Спасское-Лутовиново, 2018. № 26-2. С. 25-33. 
Сартаков E.B. Первое упоминание Гоголя в сербоязычной прессе // Русская литература и журналистика в движении времени / Московский гос. ун-т имени М.В. Ломоносова. Факультет журналистики. М., 2018. № 1-1. С. 242-250.

Сегал-Рудник Н.М. Гоголь и Достоевский в творческом сознании Вяч. Иванова 19201930-х годов // Русская литература и философия: пути взаимодействия / Отв. ред. и сост. Е.А. Тахо-Годи. М.: Водолей, 2018. - (Сер. «Русская литература и философия: пути взаимодействия». Вып. 1). С. 320-340.

Славутин Е.И., Пимонов В.И. Структура сюжета: сб. статей / Предисл. Е.В. Жаранова. 2-е изд., стер. М.: ФЛИНТА, Наука, 2018. 172 с. 200 экз.

Из содерж.:

Как все-таки сделана «Шинель» Гоголя? С. 124-135.

[Впервые: Известия Самарского научного центра Российской академии наук. Социальные, гуманитарные, медико-биологические науки. Самара, 2017. Т. 19. № 3. С. 116-120.]

http://www.ssc.smr.ru/media/journals/izvestia_hum/2017/2017_3_116_120.pdf

Степнов А.О., Фоминых С.Ф. Чествования памяти Н.В. Гоголя (в 1902 и 1909 гг.) и «Шевченковские вечера» как инструментарий политической идентичности либеральной профессуры г. Томска // Русин. Кишинев, 2018. № 4(54). С. 126-144.

DOI: $10.17223 / 18572685 / 54 / 8$

Сухих И.Н. Русская литература для всех: от Гоголя до Чехова СПб.: Лениздат, 2018. 496 с. - (Русская литература для всех).

Николай Васильевич Гоголь (1809-1852)

Гоголек: веселый меланхолик.

Новый Гоголь: непонятый пророк.

Основные даты жизни и творчества Н.В. Гоголя.

«Невский проспект» (1834).

Всемогущий Невский: люди как предметы.

Две судьбы: трагедия и анекдот.

Финал: город-призрак.

«Мертвые души» (1842).

Поэма: Гомер, Данте, Сервантес и Чичиков.

Первая страница: образ целого.

Герой: подлец-приобретатель или воскресшая душа?

Портреты: смех и страх.

Автор: лирик и пророк.

Стиль: слова и краски.

Миссия Гоголя: наследие и наследники.

Итоги: великий треугольник золотого века.

Сытина Ю.Н. «Русь, куда ж несешься ты?»: от «птицы-тройки» до железной дороги (Гоголь, Достоевский и другие) // Проблемы исторической поэтики / Петрозаводский гос. ун-т; [редкол.: В.Н. Захаров (отв. ред.) и др.]. Петрозаводск. 2018. Т. 16. № 4. С. 115-139. DOI 10.15393/j9.art.2018.5601

Творчество Гоголя в контексте европейских культур. Взгляд из Рима: Семнадцатые Гоголевские чтения: сб. научных статей по материалам Международной научной конференции (Рим (Италия), 28 марта - 2 апреля, 2017 г.) / Департамент культуры г. Москвы; «Дом Н.В. Гоголя - мемориальный музей и научная библиотека»; под общ. ред. В.П. Викуловой. М.; Новосибирск: Новосибирский издательский дом, 2018. 240 с.: ил. Содерж.:

Summary. Аннотированное содержание на английском языке. С. 7-11.

Викулова В.П. Предисловие. С. 12-14.

Гоголь и Рим

Манн Ю.В. Повесть Гоголя «Рим», или Преодоление канонов. С.16-22. 
Джулиани Рита. В поисках римской «пропавшей грамоты» Гоголя. Россия в римских периодических изданиях (1839-1843). С. 23-31.

Викулова В.П. Экспозиционно-выставочная деятельность Московского Дома Гоголя. С. 32-40. Виноградов И.А. Значение Рима в наследии Гоголя. С. 41-51.

Анненкова Е.И. «Рим» и «Выбранные места из переписки с друзьями»: от римского текста к русскому. С. 52-62.

Bоропаев B.A. Библиотека Гоголя в Риме: возвращение к теме. С. 63-71.

Сугай Л.А. Гоголь в Риме и «Рим» Гоголя в художественной рецепции русских поэтов. С. $72-82$. Шульи С.A. Рим Стендаля, Гоголя и Феллини. С. 83-88.

Биловески Владимир. Словацкий перевод повести Гоголя «Рим» (Несколько замечаний). С. 89-94. Робинов О.Ю. Гоголь в Риме: образ писателя в творчестве Зураба Церетели. С. 95-96.

Итальянские мотивы в творчестве Гоголя

Гуминский В.М. Гоголь: освоение пространства (Италия и Россия). С . 98-109.

Гольденберг A.X. Итальянский контекст в поэтике Гоголя и традиция европейского разбойничьего романа. С . 110-118.

Падерина Е.Г. Театр и драматургия Италии в творчестве Гоголя-комедиографа: интерес, влияние, переклички, перевод. К постановке проблемы. С. 119-131.

Сартаков E.B. Трактат Данте «Монархия» и теория государственности в публицистике Гоголя. C. $132-143$.

Карташов В.С. Диалог «В саду» и занятия Н.В. Гоголя итальянским языком. С. 144-148.

Текст и контекст творчества Гоголя

Дмитриева E.E. «Вы не знаете, что такое живопись...» Гоголь и Союз св. Луки: спор колоризма и графики. С. 150-162.

Есаулов И.А. Россия с позиции вненаходимости и/или причастного видения? (Гоголевская «точка зрения» в «Мертвых душах»). С. 163-169.

Бёмиг Михаэла. Как важно иметь нос. С. 170-178.

[Повесть Гоголя «Нос» и «Физиогномические фрагменты» И.К. Лафатера.]

Страно Джакома. «Мертвые души» из России на Сицилию (Гоголь и итальянские писатели). C. 179-184.

Солонович Е.С. Джузеппе Джоакино Белли - римский поэт, открытием которого Европа обязана Гоголю. С. 185-194.

Репонь Антон. Гоголь и Салтыков-Щедрин о Западе и России (европейские впечатления). С. 195-199.

Соливетти Карла. Ренато Поджоли читает Гоголя. С. 200-208.

Вокруг второго тома «Мертвых душ»: материалы круглого стола

Манн Ю.В. Вступительное слово. С. 211-218.

Балакшина Ю.В. Второй том «Мертвых душ»: в поисках новой целостности. С. 219-225.

Рипинская Е.В. «Обрыв»: к вопросу о межлитературных связях (Гоголь и Гончаров). С. 226-232. Сведения об авторах. С. 233-239.

Сегал-Рудник Н.М. Гоголь и Достоевский в творческом сознании Вяч. Иванова 19201930-х годов // Русская литература и философия: пути взаимодействия / Отв. ред. и сост. Е.А. Тахо-Годи. М.: Водолей, 2018. - (Серия «Русская литература и философия: пути взаимодействия». Вып. 1). С. 320-340.

Степанян К.А. Почему люди в первом романе Достоевского - бедные? // Достоевский и мировая культура: филологический журнал / Институт мировой литературы им. А.М. Горького РАН. М., 2018. № 2. С. 44-84.

[Роман Ф.М. Достоевского «Бедные люди» и повесть Гоголя «Шинель».]

DOI: 10.22455/2619-0311-2018-2-44-84

Тоболова М. Религиозные взгляды Н.В. Гоголя в книге «Выбранные места из переписки с друзьями» // Русская народная линия. 19.07.2018 (ruskline.ru).

Трубеикова Е.Г. Глаз и оптические средства: деформация зрения в прозе Владимира Набокова // Вестник Томского гос. ун-та. Томск, 2018. № 429. С. 58-65.

[С. 58: «В.В. Набоков - исследователь литературы у изучаемых писателей - ценил умение видеть, обращал внимание на их зоркость к миру. Так, в лекции о Гоголе он сравнивал отличие зрения ав- 
тора «Ревизора» и «Мертвых душ» от зрения среднего читателя и среднего писателя с различием «между человеческим зрением и тем, что видит фасеточный глаз насекомого», а далее отмечал, что до появления Гоголя и Пушкина «русская литература была подслеповатой. Небо было голубым, заря алой, листва зеленой... Только Гоголь (а за ним и Лермонтов, и Толстой) увидел желтый и лиловый цвета» (Лекции по русской литературе. М.: Независимая газета, 1996. С. 88).]

<Тургенев И.С.> И.С. Тургенев и мировая литература: Материалы международной конференции к 200-летию писателя, 17-19 октября 2018 г. / Институт мировой литературы им. А.М. Горького РАН; редкол.: А.В. Коровин, В.В. Пешкова, Е.А. Самофалова, отв. ред. М.И. Щербакова. М.: ИПО «У Никитских ворот», 2018. 116 с.

Из содерж.:

Виноградов И.А. Гоголь и пути русской литературы: восходящее и нисходящее (Ф.М. Достоевский, И.С. Тургенев и др.). С. 22-24.

Дерюгина Л.В. От смешного до великого... : Иван Тургенев о Гоголе. С. 37-38.

Зайцева И.А. Гоголь. Три портрета пером И.С. Тургенева. С. 42-44.

Шульи С.А. Гоголевские аллюзии в повести Тургенева «Дневник лишнего человека». С. 102-104.

$<$ Тургенев И.С.> И.С. Тургенев pro et contra: личность и идейно-художественное наследие Тургенева в оценках отечественных писателей, мыслителей, исследователей: антология / Русская христианская гуманитарная академия; сост., вступ. статья и коммент. И.Н. Сухих. СПб: Изд-во РХГА, 2018. 1168 с.- (Русский Путь).

[Указ. имен.]

<Тютчев Ф.И.> Ф.И. Тютчев: pro et contra: личность и творчество Тютчева в оценке русских мыслителей и исследователей: антология / Русская христианская гуманитарная академия; сост., вступ. статья и коммент. К.Г. Исупова. СПб: Изд-во РХГА, 2018. 1040 с.- (Русский Путь).

[Указ. имен.]

[1-е изд.: М., 2005.]

Урушев Д. С Пушкиным на дружеской ноге. Всякую несправедливость, касающуюся Александра Сергеевича, Гоголь воспринимал как личную обиду // Русский мир.ru. 2018. 15 авг. № 8. С. 56-61. www.russkiymir/ru

[М.Е. Лобанов, поэт и переводчик, академик Императорской Российской академии, как один из возможных прототипов Хлестакова.]

Успенский Б.А. Время в гоголевском «Носе» («Нос» глазами этнографа) // Успенский Б.А. Исследования по русской литературе, фольклору и мифологии. М.: Общее место, 2018. С. 73-88. [Печатается по изд.: Успенский Б.А. Историко-философские очерки. М., 2004. С. 49-68.]

Федотова А.А. «Трудный рост»: рецепция в прозе Н.С. Лескова: монография / Министерство образования и науки Российской Федерации, Ярославский гос. педагогический ун-т им. К.Д. Ушинского. Ярославль: РИО ЯГПУ, 2018. 341 с. 100 экз.

[Указ. имен.]

Фетисова T.A. <Реферат> // Культурология: дайджест / Российская академия наук. Институт научной информации по общественным наукам. Центр гуманит. науч.-информ. исслед. Отд. культурологии; Ред-сост. вып. О.В. Кулешова. М., 2018. № 4(87). С. 198 200. - (Сер. Теория и история культуры).

[Реф. статьи: Васиярова O.A. «Шинель»: авангардная киноверсия классического текста // Вестник Самарского ун-та. История, педагогика, филология. Самара, 2017. № 23(3). С. 55-59. КиберЛенинка. - Режим доступа: https://cyberleninka.ru/article/n/shinel-avangardnaya-kinoversiyaklassicheskogo-teksta]

[Киносценарий Ю.Н. Тынянова по повести Гоголя «Шинель».]

Фрумкин К. Сквозные мотивы русской драматургии: от Грибоедова до Эрдмана. М.; СПб.: Нестор-История, 2018. 280 с.

Из содерж.:

Три «Ревизора», или Загадка Бобчинского. С. 13-22. 
Хитёва Ю.С. Н.В. Гоголь и И.А. Крылов в 1830-1835 годы // Известия Саратовского ун-та. Новая серия. Серия Филология. Журналистика. Саратов, 2018. Т. 18. № 3. С. 280-285.

DOI: 10.18500/1817-7115-2018-18-3-280-285

Хренова О.М. О лирических отступлениях в поэме Н.В. Гоголя «Мертвые души» // Литература в школе. М., 2018. № 10. С. 34-35.

Чекалева К.A. «Такие загадочные вечера...» (по мотивам повестей из цикла «Вечера на хуторе близ Диканьки» Н.В. Гоголя): урок внеклассного чтения в 6-7 кл. // Научно-методический журнал Педагогический поиск / Курский институт развития образования. Курск, 2018. № 2. С. 31-35.

Чернеи Л.В. О типах персонажей в русской литературе XIX века: монография. М.: МАКС Пресс, 2018. 212 c.

[Указ. имен.]

Чехов М. О технике актера: М.: Изд-во АСТ, 2018. 288 с. - (Сер. Эксклюзив: Русская классика).

[О Гоголе: С. 111.]

[Впервые книга издана в США: Издание автора, 1946. 288 с.]

Чуйков П.Л. Н.В. Гоголь и Ф.М. Достоевский о богатырстве, учении Христовом и европейской цивилизации // Русская речь. М., 2018. № 2. Март-апрель. С. 65-72.

Чуйков П.Л. Проблема «Россия и Запад» в историософской публицистике Н.В. Гоголя и Ф.М. Достоевского, редактора журнала «Время» // Актуальные вопросы современной филологии и журналистики / Воронежский гос. технический ун-т. Воронеж, 2018. № 3(30). С. 91-97.

Шадурский В.В. Русские классики в творческом восприятии М.А. Алданова и В.В. Набокова: схождение и полемика (по материалам переписки) // Вестник РГГУ. Серия: История. Филология. Культурология. Востоковедение. М., 2018. № 2-1(35). С. 90-99. [О Гоголе: С. 95-96.]

<Шевырева С.Б.> Русские в Риме: дневник Софьи Борисовны Шевыревой [Ч. 2] / Подгот. текста, вступ. статья и коммент. А.А. Горохова; пер. с франц. М.О. Шадской // Русская политология. М., 2018. № 1(6). С. 159-177 (Продолжение следует).

[В частности, упоминания о Гоголе.]

[Ч. 1 см.: <Шевырева С.Б.> Русские в Риме: дневник Софьи Борисовны Шевыревой. Ч. 1 / Подгот. к публ. и коммент. А.А. Горохова; пер. с фр. М.О. Ноздренко // Историческое образование / Российский православный ун-т святого Иоанна Богослова. М., 2014. № 4(4). С. 171-176.]

Шишкин А.Е. Дихотомия религиозности и демонизма Гоголя // Филология и культура / Казанский (Приволжский) федеральный ун-т. Казань, 2018. № 4(54). С. 269-276.

Шокарев С.Ю., Ястржембский Д.А. Тайны дома на Никитском бульваре / Департамент культуры г. Москвы; «Дом Н.В. Гоголя - мемориальный музей и научная библиотека»; отв. ред. В.П. Викулова. М.; Новосибирск: Новосибирский издательский дом, 2018. 152 с.: ил.

Шульи С.А. Гоголь и Ж. Казот («Вий» и «Красавица по воле случая») // Slavia Orientalis. Warszawa, 2018. T. LXVII. № 1. C. 23-29.

Шульи С.A. Стендаль, Пушкин, Гоголь: к метафизике «памятника» // Вопросы литературы. 2018. №1. C. 87-112.

DOI:10.31425/0042-8795-2018-1-87-112

Шульи С. Хармс - Гоголь - Достоевский («Старуха»-«Вий»- «Преступление и наказание») // Slavica. Annales Instituti Savici Universitatis Debreceniensis / Институт славистики Дебреценского ун-та. T. XLVII. Debrecen: Debrecen University Press, 2018. C. 71-84. 


\section{А В Т О РЕФ Е РАТ Ы}

Артамонова И.В. «Наполеоновский комплекс» в русской классике первой трети XIX века: А.С. Пушкин, М.Ю. Лермонтов, Н.В. Гоголь: Автореф. дис. ... канд. филол. наук / Российский ун-т дружбы народов. М., 2018. 18 с.

Гл. 4: Наполеон в оценке Н.В. Гоголя: разоблачение героического мифа. С. 13-15.

$\S 1: 1812$ год в «Миргороде» Н.В. Гоголя: наполеоновский хронотоп. С. 14.

§ 2: Чичиков и Наполеон: от антагонизма - к двойничеству. С. 14-15.

§3: «Антинаполеоновская» модель помещичьего существования в «Мертвых душах». С. 15.

Егорова С.О. Эволюция эсхатологических мотивов в творчестве Н.В. Гоголя: Автореф. дис. ... канд. филол. наук / Волгоградский гос. социально-педагогический ун-т. Волгоград, 2018. 25 c.

Завгородний А.М. Поэма Н.В. Гоголя «Мертвые души» во французской рецепции: Автореф. дис. ... канд. филол. наук / Московский гос. областной ун-т. М., 2018. 20 с.

Макурина Н.А. Пародия в творчестве Ф.М. Достоевского: Автореф. дис. ... канд. филол. наук / Пермский гос. гуманитарно-педагогический ун-т. Ижевск, 2018. 24 с.

2.3: Аллюзия к личности и творчеству Н.В. Гоголя в повести «Село Степанченково и его обитатели». С. $18-19$.

[C. 19: «Пародия на Гоголя, как и пародийные принципы организации системы персонажей и композиции повести, обнаруживают признаки самопародии: пародируя «Переписку» Гоголя, Достоевский создает автопародию на себя будущего, которая в данном случае носит непроизвольный характер».]

3.1: Пародийные вариации на тему В.Г. Белинского.

[C. 20: «Пародия на Белинского, как и пародия на Гоголя, может быть квалифицирована как сложная межтекстовая пародия, имеющая самопародийный потенциал».]

[См. также: С. $3-4,7,11,12.18$.]

Маливанова Е.И. Мемориальная топонимика Н.В. Гоголя: историко-литературный аспект: Автореф. дис. ... канд. филол. наук / Московский гос. ун-т имени М.В. Ломоносова. М, 2018. 24 c.

Федотова А.А. Рецептивные стратегии в прозе Н.С. Лескова: Автореф. дис. ... д-ра филол. наук / Ярославский гос. педагогический ун-т им. П.Д. Ушинского. Ярославль, 2018. 38 с.

Гл. 5: «Заячий ремиз» Н.С. Лескова как пародия.

§ 2: «Заячий ремиз» Н.С. Лескова как текст-полилог.

[Гоголевский текст в повести: С. 29-30.]

Чуйков П.А. Духовное наследие Н.В. Гоголя в литературно-критической и художественной рецепции Ф.М. Достоевского (1857-1864 гг.): Автореф. дис. ... канд. филол. наук / Московский педагогический гос. ун-т. М., 2018. 25 с.

Автор-составитель / Author-composer:

Владимир Алексеевич Воропаев, доктор филол. наук

профессор

филологический факультет

МГУ имени М.В. Ломоносова
Vladimir A. Voropaev,

Doctor of Philology

Professor

Philological Faculty

Lomonosov Moscow State University

voropaevvl@bk.ru 